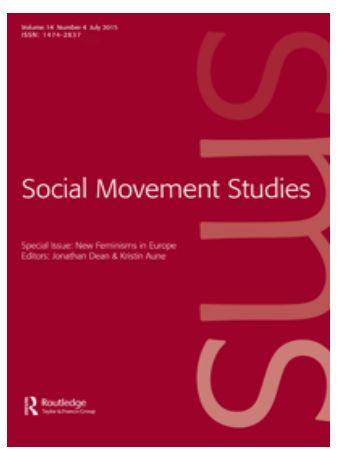

Social Movement Studies

Journal of Social, Cultural and Political Protest

\title{
Feminist Practice and Solidarity in Secular Societies: Case Studies on Feminists Crossing Religious-Secular Divides in Politics and Practice in Antwerp, Belgium
}

\section{Nella van den Brandt}

To cite this article: Nella van den Brandt (2015) Feminist Practice and Solidarity in Secular Societies: Case Studies on Feminists Crossing Religious-Secular Divides in Politics and Practice in Antwerp, Belgium, Social Movement Studies, 14:4, 493-508, DOI: 10.1080/14742837.2014.994094

To link to this article: http://dx.doi.org/10.1080/14742837.2014.994094

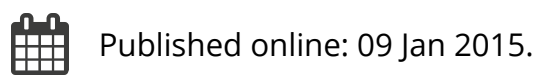

Submit your article to this journal ๘

\section{Џ Article views: 108}

Q View related articles $₫$

View Crossmark data \ulcorner 


\title{
PROFILE
}

\section{Feminist Practice and Solidarity in Secular Societies: Case Studies on Feminists Crossing Religious-Secular Divides in Politics and Practice in Antwerp, Belgium}

\author{
NELLA VAN DEN BRANDT \\ Department of Languages and Cultures, Centre for Research on Culture and Gender, Ghent University, Ghent, \\ Belgium
}

\begin{abstract}
In west European countries, public debates on migration, integration, and diversity are informed by particular understandings of secularism and the secular society. In our increasingly diverse societies, so the story goes, it is needed to implement a certain type of secularism and/or support particular types of secular standpoints in order to maintain a certain status quo that guarantees security, democracy, and equality for all. Religion is often perceived and simultaneously constructed in opposition to the emancipation and equal rights of women. This dominant logic, in which secularism and religion are opposites, makes it difficult for women of diverse religiouscultural backgrounds to cooperate on an equal footing for a shared feminist cause. However, feminist politics and practices that cross religious-secular divides can and do take place. Feminist research has so far paid little attention to the actualities of this feminist border-crossing and the transformations it may engender in our current sociopolitical context. In this article, I aim to offer a consideration of feminist politics and solidarity crossing religious-secular divides in Flanders, the Dutch-speaking northern region of Belgium. Through two case studies, I explore how cooperation and solidarity across religious-secular boundaries are developed and being talked about by activists. I argue that such feminist coalitions can and do directly and indirectly affect the public debates and inspire feminist thinking on issues regarding religion, secularism, and feminism in the multicultural society.
\end{abstract}

KEY Words: Feminist politics, transversalism, decolonial feminism, solidarity, religious-secular differences

In west European countries, public debates on migration, integration, and diversity are informed by particular understandings of secularism and the secular society. In our increasingly diverse societies, so the story goes, it is needed to implement a certain type of secularism and/or support particular types of secular standpoints in order to maintain a certain status quo that guarantees security, democracy, and equality for all (Jakobsen \& Pellegrini, 2008). Religion is often perceived and simultaneously constructed in opposition to the emancipation and equal rights of women (Mulder, 2002). The emergence

Correspondence Address: Nella van den Brandt, Department of Languages and Cultures, Centre for Research on Culture and Gender, Ghent University, Rozier 44, 9000 Ghent, Belgium. Email: hendrikapetronella. vandenbrandt@ugent.be

(C) 2015 Taylor \& Francis 
of political and public debates about and regulations of the Islamic headscarf throughout a number of European countries since the late 1980s (Kilic, Saharso, \& Sauer, 2008) is a case in point. According to Fadil (2011), the headscarf as a highly visible marker became the symbol of the religious otherness of Islam, which made Islamic veiling in Europe controversial and prone to becoming the subject of polarizing debates. The headscarf debates became one of the arenas in which the increasingly difficult and power invested relationship between white populations and Muslim migrant communities in the global post-9/11 context is played out.

In Belgium, headscarf debates and regulations have increased in number and intensity since 2004, when the French National Assembly and the Senate passed a law that bans obtrusive religious symbols, including headscarves, from the public domain. While the Belgian history of acknowledging, dealing with, and supporting various religious and nonconfessional communities could be described as a locally specific model of multiculturalism, the current debates on and regulations of the headscarf and the faceveil draw upon Republican notions of neutrality and secularism that are much more typical of the history and self-definition of France (Coene \& Longman, 2008; Bracke \& Fadil, 2009). They can therefore be seen as signaling transformations in prevailing Belgian church-state relations (Fadil, 2011, p. 87-88).

The recent situation in Flanders - the Dutch-speaking northern region of Belgium - has been one of increasing headscarf regulation in the fields of public education and the public and private labor markets. Today, headscarf-wearing girls cannot opt for public education provided by the Flemish community due to a general headscarf ban issued by the board of the Flemish network of public education in 2009. This led Amnesty International to charge the policies of the board with discriminating against Muslim girls in their exercise of human rights, as well as the Flemish Ministry of Education for not taking a stance on the introduction of a ban on religious symbols applying to pupils in public education (2012, p. 63-65). Coene and Longman (2006) point out that many of the protagonists in the debates talked about but not with Muslim women about their experiences with and understandings of the headscarf. This exclusion generated activism by Muslim women, who insisted their voice would be heard and their experiences recognized. For example, between 2004 and 2007, the autonomous women's groups AMV (Action Committee Muslim Women in Flanders) and BOEH! (Boss Over One's Own Head) were established to argue and petition against headscarf bans at public schools (2006, p. 184).

The civilizational and assimilation rhetoric that is part of the headscarf debates and regulation draws upon stereotypical images of the veiled Muslim woman. This rhetoric structures the gendered religious-secular divide as it sets up an 'us' and 'them' relationship between white secular women and Muslim women based on the assumed treatment or positions of women. The dominant discourse that sees white women as emancipated (from religion and patriarchy) and Muslim women as oppressed (by religion and patriarchy) obstructs the possibilities for progressive coalition building and collaboration across ethnic and secular-religious divides on an equal footing for a shared cause (Reilly, 2011). It also puts white Christian feminists in a nearly 'unavailable' position (Najmabadi, 2008). White women's organizations in Flanders are divided regarding their viewpoints on the possibility of women's emancipation from within religious tradition or identity in general, and on Islam and the headscarf and its regulation in particular (S'Jegers, 2005). While Christian feminism exists in Flanders since the first wave feminism (Latré, 2011), this movement is hardly part of current public memory and 
consciousness (van den Brandt, 2012). At the same time, and on a small scale, feminist conversations and practices that cross religious-secular divides do take place. Feminist research has so far paid little attention to the actualities of this feminist border-crossing and the transformations it may engender in current west European sociopolitical contexts.

In this article, I therefore offer a consideration of feminist politics and solidarity crossing religious - secular divides located in Flanders. I approach two contemporary cases of feminist solidarity across religious-secular differences with the following questions: How is feminist cooperation and solidarity across religious-secular boundaries developed and talked about by feminist activists? Do they talk critically about the way they develop solidarity across religious-secular differences? How do they reflect on and deal with specific obstacles, if there are any? Does feminist coalition-building across religioussecular boundaries lead to rethinking feminism in secularized multicultural societies? I argue that the two feminist groups discussed in this article can and do directly and indirectly affect the public debates and inspire feminist thinking on issues regarding religion, secularism, and feminism in multicultural society.

I structure the article as follows. First, I rethink the assumed tension between feminism and religion and argue for recognizing the work that cooperation and solidarity building across religious-secular differences require. Second, I discuss the concepts of 'transversal politics' and 'decolonial feminism' as approaches to feminist politics and solidarity across religious-secular divides. Third, I draw on two case studies of feminist initiatives in order to think about the possibilities for a more inclusive feminist solidarity. Both case studies, I will show, offer challenging perceptions on and practices of feminist solidarity in current west European secular societies.

\section{The Study of Feminism, Religion, and Solidarity Across Differences}

Since the emergence of the academic wing of the feminist movement - women's studies and, later, gender studies - the study of women, feminism, and religion presents particular challenges. Religion and feminism in Europe have a historically tensioned relationship. As heirs to the Enlightenment rationalist critique of religion, the public voice of west European second wave feminisms was often anti-clerically oriented. Feminist thinkers and activists challenged traditional discourses on femininity and masculinity linked to ideals about proper roles and positions for men and women in religion and society. They critiqued the visions and power of religious (notably Christian) authorities in dictating religious beliefs and practices and gendered hierarchical relationships (Braidotti, 2008). Second wave feminism has supported women to take a critical distance vis-à-vis religious authorities and imaginaries (Aune, 2011). In many narrations about second wave feminism, religion appears rarely and mostly as a source of opposition (Braude, 2004). In a survey held recently among a large group of British feminists, Aune (2011) reveals that feminists in general are less supportive of traditional religion and are more engaged with and/or supportive of the so-called 'alternative' or non-institutional religiosity and spirituality. She suggests three main reasons as explaining this phenomenon: feminism's historical alignment with secularism (Braidotti, 2008), the role of feminism within secularization and the so-called 'decline of religion' as a gendered historical development differentiated along religious and ethnic demarcations (Aune, Sharma, \& Vincett, 2008), and the connections between feminism and alternative spiritualities (Woodhead, 2008). 


\section{Rethinking the Religious-Secular Divide in Western Feminism}

Over the last decade or so, heated debates have taken place among feminist scholars and activists on the relationship between feminism and religion, culture and tradition within multicultural societies, famously captured under the phrase 'feminism versus multiculturalism debates'. In 1999, Okin was the first to put gender on the agenda of theorizations of multiculturalism and initiated the emergence of a new interdisciplinary research focus on feminism and religious-cultural diversity in multicultural societies (e.g. Coene \& Longman, 2005). Okin posed the question of how to deal with demands of religious, cultural and/or ethnic minority groups within liberal-democratic societies when they contradict the norm of gender equality, formally endorsed by liberal states. Her essay put religion and tradition in opposition to the autonomy and interests of women. It evoked many critical reactions regarding the normative 'universality' of liberal values; the negative, generalizing and static depiction of non-Western cultures, traditions and religions; and the fear of the Other that seems inherent to it (e.g. Al-Hibri, 1999; Honig, 1999; Parekh, 1999). To these critical remarks I would add that Okin's assertions spring from an invisible positioning as a Western liberal, secular feminist. She claims that violations of women's basic human rights - freedom from discrimination, control of movement and violence, and freedom to bodily integrity - are predominantly practiced on the basis of religious-cultural precepts in the private sphere of family life (Okin, 1999). Secularisms as political systems organizing the role and space of religion in politicalsocial life and secularity as epistemological standpoints are not mentioned in relation to women's rights and agency and remain the uninvestigated norm for women's emancipation (Butler, 2008; Jakobsen \& Pellegrini, 2008; Mahmood, 2005; Scott, 2009). Okin's vision on religion as based on the past to set up undemocratic and illiberal rules for the present is at least partly determined by the historical tensioned relationship between Western secular feminism and religion. Since the fierce anti-clerical stance of part of second wave feminism, secularism came to stand for the liberation and emancipation of women. Scott (2009) problematizes this dominant notion of secularism. Her research on the history of the French revolution and her 'genealogy of secularism' demonstrate that the history of the French revolution did not automatically and without feminist struggle lead to an understanding and application of women's equal rights. An unambiguous historical relationship between the separation of church and state and improvements in the status of women can therefore not be taken for granted.

The danger of a dominant discourse that equates secularism with women's rights and emancipation is that it makes it difficult to see and recognize historical and current forms of affirmative relationships between feminism and religion (Braude, 2004). It may silence the many efforts of religiously inspired feminists - past and present - and the socialpolitical and religious transformations they helped to generate both within their own religious communities and society at large. Throughout the history of European feminism, women have struggled for the betterment of the status and position of women, both outside and within religious communities, and have been inspired by religious understandings of social justice (Decoene \& Lambelin, 2009; Jansz, 2008). It may lead secular feminists to take religious feminists less seriously when the latter continue privileging a critical commitment to their own tradition and attempt to reform it, rather than a total rejection of religious tradition and identity. It can also lead to (support for) (violent) impositions of secularism abroad in imperialist projects (Eisenstein, 2004; Mahmood, 2005) or secular 
standpoints among certain minority groups within the nation-state (Fadil, 2011; Scott, 2007) in the name of liberating women.

The historical tension between European feminism and religion and the resulting thinking in terms of rigid secular-religious divides, currently taken up and reinforced by conservative politicians in order to promote anti-religious and xenophobic agendas (Butler, 2008; Scott, 2007), have serious consequences for the possibilities for women to connect across differences. It makes intersections between visions and activism of secular and religious feminists difficult to imagine. Exploring how cooperation and solidarity across religious-secular boundaries by feminists in Flanders are developed and talked about contributes to an understanding of narratives about the relationship between secular and religious feminists, as well as of some innovative trajectories and practices of feminism in multicultural societies.

\section{Rethinking Feminist Solidarity across Differences}

In order to approach feminist politics and solidarity across differences, I find it helpful to discuss and draw upon the concepts of 'transversal politics' and 'decolonial feminism' as articulated by feminist thinkers and activists Nira Yuval Davis and Maria Lugones. These concepts offer challenging perspectives on current feminist politics and engagements in the west European context, and will be reconsidered in the next section through two case studies of feminist border-crossing initiatives in Flanders.

In the wake of post-modern feminist theory, many posed the following crucial theoretical-political question regarding women's activism and coalition building (McLaughlin, 2003, p. 15): how and with whom can we form cooperation if we accept that we all differ regarding our social positionings and that a foundational claim or position as a basis for critical theory and political engagement does not exist, as methods of deconstruction have abundantly made clear? Yuval-Davis (1997) proposes the concept 'transversal politics' as a normative model for future feminist coalition building. Transversal politics is based on a common (temporary) cause and message. Feminist and/ or community activists are not seen as representatives of their constituencies assuming a shared identity and subsequent needs and political claims. Instead, activists are advocates, working to promote their cause. This also means that advocates do not necessarily have to be members of the constituency they advocate for (Yuval-Davis, 2008). Furthermore, transversal politics is based on a dialogical standpoint epistemology. Mobilizing takes place in the awareness of the fact that the mobilized group is a political construction, not a natural given. Such a coalition is based upon dialog and the continuous process of rooting and shifting - meaning the awareness of being rooted within one's own identity and membership of particular communities, and the act of placing oneself in a situation of exchange with women from different backgrounds and identities. It leaves behind imaginations of unity and homogeneity and acknowledges the specific positioning and partial knowledges of its participants. Transversal politics follows the principle of the encompassment of difference by equality (Yuval-Davis, 1997, 2008). Yuval-Davis' model for feminist coalition building has proved challenging and encourages feminist scholars and activists to move beyond the impasse of the discussions about identity politics. It argues for the importance of achieving acceptance and inclusion of difference within coalition work. However, the model of transversal politics does not thoroughly rethink the problems of power inequality between women in coalition building. As Bulbeck (1998) 
writes, 'coalition work should not mean the incorporation of the less powerful within the framework of views and goals of the most powerful, but should instead be the act of balancing on 'the tightrope of connection, distance and power' (p. 221). When it comes to feminist solidarity among women of different ethnic, cultural, and/or religious backgrounds, issues of inequality regarding voice, visibility, recognition, resources, social advantages, and privileges on the intersections of gender, ethnicity, and religion pose serious barriers for collaboration for a common cause (Nyhagen-Predelli \& Halsaa, 2012).

Lugones (2010) therefore speaks of the necessity of a decolonial perspective in order to make coalitions across power-invested differences sustainable. A common feminist cause, then, is not enough. Lugones points to the colonialist and imperialist impositions of Western gender discourses and systems on non-Western people. A 'decolonial feminism' should offer the possibility of overcoming the 'coloniality of gender' - the decolonization of imposed gender discourses and systems. It is to enact a critique of racialized, colonial, and capitalist heterosexist gender oppression as a lived social transformation. Lugones takes the starting point of decolonial feminism as coalitional. In order to work toward fruitful collaborations, she proposes to learn about and see each other anew as resisters to the coloniality of gender. Communities rather than individuals enable resistance, understanding, and recognition. Where Yuval-Davis argues for the necessity of the inclusion of difference through dialog and the process of rooting and shifting, Lugones (2010) asks us to think of how we deal with the power inequalities involved. Decolonial feminism puts an emphasis on politics of location and a maximal sense of responsibility and methodologies that work with our own lives. Coalition work needs to be constantly reflected upon by posing questions such as:

How do we learn about each other? How do we do it without harming each other $[\ldots]$ ? How do we cross without taking over? With whom do we do this work? [...] How do we practice with each other engaging in dialog at the colonial difference? (2010, p. 755)

Lugones' conceptualizing of decolonial feminism critically speaks of feminist coalition building across differences. However, when she speaks of coalition building, she refers to subjects of resistance toward the modern/colonial gender system. In Lugones' writing, subjects of resistance share a history of colonial difference. This would imply that coalition building by white secular majority women and non-white religious minority women crossing the power-invested borders of racial, ethnic, cultural, and religious differences, is near to impossible or necessarily brings along or reinforces colonial or imperial violations. Is that necessarily the case? How to bring women's multiple subjectivities and positionings in terms of privilege and disadvantage into rethinking coalition buildings across differences? How to think, for example, of the place of European white religious feminists in such collaborations - who are privileged at the level of race and culture but 'invisibilized' due to their religious identity? I demonstrate below that feminist solidarity across ethnic and religious-secular divides is possible, though it needs critical awareness of power inequalities and the multiple subjectivities of women. It also needs considerable mutual engagement, as many barriers exist on the practical level of defining agendas and terminology, but also on the psychological level of trust and confidence. Lugones' pressing questions regarding how to sensitively cross borders 
remain of high importance when considering feminists crossing religious-secular divides in the west European context.

\section{Case Studies on Feminists Crossing Religious-Secular Divides in Politics and Practice in Antwerp, Belgium}

I explore feminist politics and practices crossing religious-secular divides through drawing attention to the work being done and reflections made by two particular feminist groups in Antwerp. Although they differ regarding their histories, degree of institutionalization, resources, and area of action, both are part of the public debate in various ways, such as through writing critical opinion pieces in newspapers and/or organizing lectures, debates, and workshops. Both continue internal discussions about public debates and policies in relation to their own responses and practices. Both groups are made up of self-defined religious and non-religious actors and are committed to feminist ideals. These aspects make the two groups relevant foci for a discussion of feminist politics crossing religious-secular divides. They cannot be considered as representative of feminism in Flanders. Although both are in their own ways vocal and visible, they need to be considered as situated rather at the critical margins of what is considered feminism in Flanders - precisely because of the fact that their work and activism are focused on topics that are perceived to be religious.

The first group considered is Baas Over Eigen Hoofd! (Boss Over One's Own Head! BOEH!). This is an autonomous feminist platform that campaigns against the regulation of headscarves. Established in 2007 in Antwerp, it is by now a widely known group, as its activism has occasionally reached a broad audience through media coverage. ${ }^{1}$ The second is Motief, which since 2008 has operated as a pluralist organization in Antwerp, but originally comprises Protestant progressive social educators and Catholic liberation thinkers and activists. Today, Motief provides education about social-political, religious and faith issues from a progressive perspective, in which it aims to include feminist perspectives. $^{2}$ This means that while BOEH! starts from a specific women's issue and feminist perspective, Motief starts from its commitment to opening up debates about religion and faith, and complements this with feminist perspectives. The case study of BOEH! focuses upon its activism and the visions of its activists. The case study of Motief focuses upon a moment of internal reflection, through its organization of a reading group on religion and feminism, and focuses on the experiences of the participants of the reading group.

I conducted the case studies using multiple methods, such as analysis of written material, interviews, and participant observation. According to Hesse-Biber \& Leavy, case study research should be regarded as a research strategy. Because it enables complex, nuanced, and in-depth understanding of the subject of inquiry, it is often performed with social justice purposes in mind (2011, p. 255-256). Case study research is always partial and cannot claim to give a representative account of the issues under investigation. Instead, it should aim to provide detailed understanding of these issues from the perspective of a few cases, which might shed some new light on the subject in general (Flyvbjerg, 2004).

Intellectually raised in the traditions of feminist methodologies and qualitative research methods, I believe in the importance of discussing the position of the researcher - an issue that has been extensively questioned and debated among feminist qualitative researchers in 
terms of researcher's 'insider' and 'outsider' positions to the community or group he/ she studies (Acker, 2000; Collins, 1991; Naples, 1996). The 'insider' and 'outsider' terminology, however, should not be taken as referring to clearly delineated and fixed positions. As Acker (2000) argues, the researcher's multiple subjectivity allows her/him to be both insider and outsider simultaneously and to shift position back and forth. This happens not always at will, but with some degree of agency. I shift position as 'insider' and 'outsider' on several levels in relation to the case studies. Coming from Holland to conduct fieldwork among feminist groups in Flanders affords me both advantages and disadvantages in my research. Although a foreigner by nationality, by virtue of my whiteness, I am considered to be part of the cultural majority and treated as such. My secular standpoint determines the way I am perceived and responded to by both religious and non-religious research participants. When it comes to BOEH! and Motief, I am an outsider to the work of BOEH! and partially an insider to Motief as I was a participant in its reading group on religion and feminism. While I perceive BOEH!'s activism from an outsider's sympathetic perspective, I played some role in how Motief's reading group developed regarding the topics of discussion and the perspectives brought in.

In the analysis of the case studies below, 'crossing the religious-secular' divide refers to believing and non-believing women collaborating in a feminist alliance. The distinction between believing and non-believing is somewhat misleading as it assumes two fixed categories. However, I use the terminology of religious and secular feminists here to draw attention to different sources of inspiration and strength, whereby religious or believing feminists find direct and conscious inspiration in their struggle for justice in traditional monotheist religions such as Christianity and Islam, while secular or non-believing feminists are not directly or consciously inspired by religious values or truths.

\section{BOEH!: Developing and Reformulating Feminist Solidarity}

BOEH! was founded in January 2007 in protest at the introduction of a headscarf ban for employees of the Antwerp city council offices. Its activities include taking part in debates in cultural centers around issues such as diversity and emancipation and contesting in court the headscarf ban issued by the board of the Flemish network for public schools. In BOEH!, white secular feminists cooperate with Muslim feminists of Moroccan migrant backgrounds. The activists vary not only regarding ethnic-cultural backgrounds and religious-secular life stances, but also regarding age and organizational affiliations. BOEH!'s activism has some social-political impact as it contributed to mobilizing formerly politically passive Muslim communities, and to triggering further debates within the women's movement about emancipation and cultural-religious diversity. Between November 2010 and April 2011, I interviewed several BOEH! activists. I conducted four interviews with white secular women of different ages and four interviews with Muslim women of Moroccan background in their 20s and early 30s. I analyzed the interview narratives with a focus on the ways in which feminist and antiracist solidarity across differences is developed and discussed.

\section{Feminist Activists Developing a Shared Struggle}

BOEH! started as an action platform against Antwerp's policy regulation of the headscarf. While BOEH! makes claims based on the position and experience of Muslim 
women, the activists were able to build an alliance across religious-secular and ethnic boundaries based on a social-political message that connects women across differences. The activists' critical discourse revolves around notions of women's freedom of choice and freedom of religion as a human right. They endorse a critical liberal-secular feminist standpoint and enlarge notions such as 'autonomy' and 'freedom of choice' in order to embrace the wearing of the headscarf within the liberal framework (Mahmood, 2005, p. 195). They condemn any form of discrimination against ethnic, religious, and gendered identities.

BOEH! members perceive their message as enabling broad-based feminist solidarity as it argues for respecting and protecting women's choices that necessarily differ depending on ethnic, cultural, and religious backgrounds and social positionings. As Yuval-Davis would put it, 'it is the message, not the messenger, that counts', which does not mean that it is totally immaterial who the messenger is (2008, p. 282). Fleur, a white secular activist, linked BOEH!'s message and solidarity during the interview as follows:

Our message is indeed a typical feminist solidarity message, saying that those men in the town hall shouldn't act as if they know how things work for women, because we know it ourselves, and they also shouldn't think that they can put us against each other, because we are already connected. We are connected, and we find each other on various themes. We want to live together and just be free in our decisions.

Fleur recognizes the ongoing political and public headscarf debates in Flanders and the ambiguous position of women's organizations within these debates, as a barrier to peaceful (feminist) multicultural coexistence. According to Eisenstein (2004), in order to connect women across differences, it is imperative especially for majority of women to criticize colonizing discourses that appropriate feminist values and implicate white 'liberated' women in political-imperialist agendas. The white BOEH! activists would probably agree with this. While BOEH! recognizes that differently situated women need to cope with different types of discrimination, in building a feminist alliance and politics they strategically choose to underline the connections among women as women. At the same time, BOEH! acknowledges that different paths toward emancipation exist, and recognizes religion (Islam in particular) as possibly supportive of claims for women's rights and agency.

The feminist discourses and practices of $\mathrm{BOEH}$ ! decolonize dominant discourses that emphasize hierarchical differences among women and impose normative models of emancipation on migrant women. It disentangles itself from the imagined secular/ religious, modern/backward, and liberated/oppressed divide. However, the fact that BOEH!, situated within a secularized society, strategically opts for using liberal-secular language and avoids religious terminology in writing and claims-making can be at times a sacrifice for Muslim women who in their activism partly draw on religious inspiration and critique. The next case study discusses the issue of the inequality of secular and religious language in the public sphere more in depth.

\section{Normative Thoughts on Feminist Solidarity}

During the interview conversations, BOEH! activists severely criticized exclusive and paternalistic expressions of solidarity. Individually, they offered ways of rethinking the 
meaning and practice of solidarity, such as by starting from a shared message or women's situated needs, emphasizing solidarity as an open-ended process based on mutual empathy, or rejecting the concept of solidarity altogether as it might be understood in contrast to the idea of a shared struggle. The activists' engagement in processes of 'rooting' and 'shifting' (Yuval-Davis, 1997) resulted in growing insights into the diverging positionings that women from different cultural, ethnic, and religious-secular backgrounds take up in multicultural societies and the privileges or disadvantages that these positionings bring with them. It resulted moreover in the construction of BOEH! as a transversal political space in which various feminist voices can be articulated and heard. Some activists formulated normative visions for women's connectedness in multicultural societies. Their visionary feminism (Hooks, 2000) does radically away with dominant thinking in terms of fixed and hierarchical categorizations and an incompatibility of religious and secular modes of existence and resistance. An illustration can be found in the formulations of Layla, a Muslim BOEH! activist:

[Y] es all of us with our limited personal motivations came to the table where eventually BOEH! was founded. "We" had at that time a very limited meaning. [...] But [it became] a struggle belonging to all of us. [...] And here it touches upon the discussion about solidarity. It is not any longer about "we" and "them", it is just "we". Our struggle, all of us.

Layla offers a vision of feminist community building based on her personal experiences and growth within BOEH!. The activists learned to understand 'community' in new ways. BOEH!'s coalition building and activism across religious-secular differences became a transformative practice for the activists, individually and collectively. The sense of community that the activists elaborate upon can be regarded as an example of the 'we' advocated by Weir (2008, p. 127-128) as a transformative new identity that is possible through an orientation to solidarity, a commitment to holding together, not through suppression of critique and internal discussion but through engagement, as well as through an identification with this new form of feminist community.

\section{Motief: Critical Conversations Across Differences}

Motief pursues the aim of contributing to an equal and inclusive multicultural society by drawing inspiration from Christianity, socialism, and feminism. In March 2011, Motief set up the women's reading group 'Feminism and Religion'. The first six meetings focused on the issue of feminist solidarity and coalition building across ethnic and/or religious-secular differences. They had an intellectual as well as a practical outlook, which means that the discussions featured reflections on daily life issues as well as on the methods of social movements and feminist initiatives in Flanders in general, and Motief and BOEH! in particular. The eight participants hold secular (non-religiously inspired) and religious (Islamic/Christian) worldviews, have different ages and belong to women's organizations and/or academia. I was invited and joined the group. I conducted interviews with the reading group's members (including Motief employees) from February until May 2011 in order to better understand its outcomes in terms of personal insights and visions on the possibilities for feminist conversations and solidarity across religious-secular divides. 


\section{Building a Space of Solidarity}

All members of the reading group are conscious of the gap that exists between secular and religiously inspired feminists in women's movements in Flanders. Often this refers to a gap between white secular feminists and Muslim ethnic minority feminists. However, feminisms and white feminists inspired by Christianity can also be disregarded or frowned upon by secular feminists. The gap is explained by pointing to the political histories of second wave anti-clerical feminism. This historical background provides current secularminded feminists with a collective memory that is colored with anti-religious sentiments, resulting in explicit or implicit hostility and/or misconceptions regarding religion, religious women, and religiously inspired feminists. During the group conversations, the issue of lack of trust between secular and religious feminists was often touched upon. Lugones speaks here of the communicative side of barriers to coalitions. She points at the impact of lack of recognition by majority feminists 'of the intersectionality of oppressions as real and important for struggle' for minority feminists (2006, p. 76). All participants joined the reading group with the expectation of learning something about feminist solidarity across differences in general, or across religious-secular boundaries more specifically. During the interviews, most participants pointed to the importance of the reading group as a location where in-depth conversations between religious and secular feminists were taking place and encouraged, as such feminist spaces currently do not exist elsewhere in Flanders. Some observed their delight in noticing that first of all, these conversations can be done in a respectful manner with openness to listen to other voices, visions, and experiences, and second, that the meetings prove to be insightful and inspiring. The meetings led to the establishment of a group of feminists from a variety of backgrounds who are committed to continuing their conversations and discussions, and to mutual learning and support. Lugones might speak here of the achievement of a coalition at the borderlands where double visions are developed through 'world-travelling' (2006, p. 78-79). In that sense, the reading group as a transversal feminist space became a location of decolonizing solidarity. An illustration of this sense of solidarity can be found in a quote from Rosanne, a white Catholic feminist in her early 30s:

For me it is of foremost importance that this location will continue to exist. [...] Yes, that is my question, where can we go from here? I think ... for me it is about having a place of which I know that there are people who are different but at the same time have something very much in common. And that I can be inspired there or check my own vision [with others] to start changing things in the world around us.

In Rosanne's experience, the reading group is a place where women differ from each other in many ways, but simultaneously share things, and a place where she can be inspired. It is about 'identification-with', instead of sharing a common identity (Weir, 2008). For Rosanne, this solidarity inspires and supports a critical feminist stance and creativity in working and daily life.

\section{Critically Rethinking Inequalities in Coalition Building}

Insights regarding the dominance of liberal-secular language and thinking were formulated during several meetings in which feminist writings were discussed. The 
presence of liberal-secular - or 'secularist' - language in Flemish public debates in general (Bracke \& Fadil, 2009), and in women's organizations in particular, has several impacts for religiously inspired feminists. It means that the visions, language, and motivation of religious feminists, when made explicit in religious terms, are rendered suspect or 'other' within secular feminist circles. This leads to the marginalization of other-than secular voices and/or the assimilation of religious feminists to secular language and ways of thinking. Hajar, a member of the reading group and one of the Muslim BOEH! activists, elaborated on this problem during the interview, in which she reflects on the work of BOEH!:

We always take the dominant group as a starting point, also when we want to discuss [Muslim] minority communities and their rights, also in that case we use the language of secular women. I notice this in BOEH!. In fact, in BOEH! we choose explicitly for that [use of secular language] because we thought if we want to communicate [our argument] in an understandable way to others and if we want to make our case, then we need to decide to use secular language. Yes, it is a strategic choice. Religious language is seen as odd, and just because you deal with religion, you would never be regarded as feminists. But if you start from the idea that we as women support freedom of choice and if this freedom of choice results in a headscarf, than that is possible, it should be okay.

The BOEH! activists had to find a shared framework for their argumentation against the regulation of Muslim women's clothes in public spheres, one that is understandable for and can be heard by a broader public, including politicians and policy-makers. They choose to situate their arguments within the liberal-secular language of the human rights framework (Hewitt, 2011), one might say a 'strategic liberalism', while remaining aware of some of the problems that surround claims based on individual and autonomous freedom of choice. ${ }^{3}$ Interestingly, due to the problematization of the norm of secularity during several meetings of the reading group, some secular participants - including myself - became more aware of the fact that their secularity is a normative and powerful position but by no means neutral or more objective than the standpoints of religiously inspired women. Anne-Sophie, white and an unbeliever, formulated this process as follows:

Yes, it is indeed true that those things you found self-evident or neutral are suddenly not self-evident or neutral anymore. Yes, maybe it happens more easily to nonbelievers, that they see themselves as neutral.

The 'complex conversations' (Lugones, 2006) across religious-secular differences appear to be an effective instrument to reveal norms that were to some invisible before. For example, a discussion of language mechanisms led to the awareness of the relevance of posing questions regarding inclusions and exclusions connected to the use of a certain language or concepts. Revealing the social-historical constructedness of secular standpoints has some parallels with critical research on whiteness (Frankenberg, 1997). The focus on both secularity and whiteness - interrelated categories in the west European mind-set - marks and critiques social positionings and standpoints that were previously invisible. It remains of utmost importance to name, deconstruct, and fragment notions of 
secularity and whiteness as contributions to an ongoing critique of racism and oppressive forms of secularism in western Europe. These types of awareness-raising can be transformative when rethinking and redoing feminist solidarity and coalition building across differences. The group conversations and bridge buildings simultaneously challenge the established political and media language of modernity, universalism, nationalism, religion, and secularism (Eisenstein, 2004, p. 210). According to Weir, transformative politics are politics including self-critique and self-transformation, and transformation of the group into a 'we' (2008, p. 112). The group conversations lead to the shared conclusion that only with awareness of power relations and continuous selfreflection, and posing the question of the inclusions and exclusions of language, visions, and practices, feminist coalitions can be build across differences in sustainable ways.

\section{Conclusion}

In this article, I aimed to provide a consideration of feminist discourses on and practices of coalition building and solidarity crossing religious-secular divides in Flanders. I posed the question of how feminists involved in alliances across religious-secular differences talk about and develop solidarity and cooperation. I demonstrated the ways in which $\mathrm{BOEH}$ ! and Motief critically rethink and practice feminist solidarity in the context of a secularized multicultural west European society. Both BOEH! activists and Motief participants discursively and practically deconstruct the religious-secular divide in feminism and the image of religious women as for-ever not emancipated. They moreover talk about the problem of mechanisms of inequality originating from the normativity of secular-liberal language and models of emancipation and lack of recognition of other types of feminist language and emancipation, which necessarily plays a role when building coalitions across religious-secular differences.

The discursive (de)constructions applied by BOEH! activists and Motief participants open up new imaginings for inclusive European feminisms. The Motief participants especially spoke about the possible barriers toward coalition building and reflected into depth upon the problem of the dominance of secular discourses as a common ground when speaking of women's rights and emancipation. While critical of the idea that emancipation can only be established within secular political systems and from secular epistemological standpoints, in feminist political alliances across difference it seems to be very difficult to go beyond the dominance of secular discourses. Rethinking feminism from this critical point of view leads me to posit that feminism in west European multicultural societies should not be necessarily secular but should open up for recognizing and including feminist voices based on religious terminology and experiences as well. It is clear that normative secularity does not always enlarge women's equality and agency. I believe that this critically opening up of feminist language, conversations, and claims-making in the context of west European secularized multicultural societies and current secularist politics, in which especially Islamic language and practices are rendered suspect, remains one of the main challenges for the future.

At the same time, the decolonizing work in terms of coalition building between secular and religiously inspired feminists by BOEH! and Motief already has some social-political impact. Within the women's movement in Flanders, BOEH! remains a unique and surprising political alliance that seems to make some feminists feel uncomfortable and that provokes renewed feminist debates about diversity, emancipation, and religion. Motief has taken up the challenge of discussing these issues and, like BOEH!, turned out to be a space 
of solidarity across religious-secular differences. It functions as a breeding ground for new inclusive feminist visions that still need to prove their practical worth when brought by the participants to their organizations and/or academic work. The coalition building and conversations across religious-secular differences as practiced by BOEH! and Motief importantly engender new and previously 'unimaginable' grassroots solidarities and feminist communities.

Decolonizing transversal feminisms, in the west European polarized political-social context, is, I have come to believe, about working against the grain of dominant discourses that emphasize hierarchical differences among women and impose normative white secular models of emancipation on non-white and/or religious women. Transversal feminist politics brings a decolonizing political message when it forges unexpected connections among women. Working consciously with a decolonizing perspective remains important, as transversal coalition building always takes place within powerinvested domains and relationships between people. A decolonial perspective needs to be continuously emphasized and trained; it does not come along naturally to anyone. The Motief conversations between secular and religiously inspired feminists convincingly showed that critical openness toward discovering blind spots based on preconceptions or invisible privileges is a precondition for progressing both as individual feminists and as a feminist collective. An affirmative and diverse feminism for the future, therefore, includes a self-critical attitude and awareness of the partiality of one's own standpoint and experiences, but also a readiness to cross lines that were unimaginable before and a commitment to make new solidarities possible.

Working toward inclusive feminisms in a world ridden by political, social, and economic inequalities is probably a never-ending process. A lot of thinking about and working toward inclusive feminisms in multicultural west European societies in general, and Belgium in particular, continuously needs to be done, I believe, through the building of new bridges in which women discover each other in transformative actions across diverse currents.

\section{Acknowledgements}

Draft versions of this paper were presented in the Utrecht research seminar on religion, gender and (post) secularities, convened by Anne-Marie Korte, and at the 2012 Feminist Conference in Budapest, Hungary. The author wishes to thank the participants, particularly Kathrine van de Bogert, for their helpful questions and comments. Many thanks go to the anonymous reviewers of this journal for their insightful feedback.

\section{Disclosure statement}

No potential conflict of interest was reported by the author.

\section{Funding}

This work was supported by the Special Research Fund (Bijzonder Onderzoek Fonds - BOF) of Ghent University [grant number BOF10/STA/080].

\section{Notes}

1. http://www.baasovereigenhoofd.be.

2. http://www.motief.org.

3. Claudia Brunner proposed the phrase 'strategic liberalism' in response to my paper at the 8th Feminist Conference in Budapest, 2012. 


\section{References}

Acker, S. (2000). In/out/side: Positioning the researcher in feminist qualitative research. Resources for Feminist Research, 28, 189-210.

Al-Hibri, A. J. (1999). Is western patriarchal feminism good for third world/minority women? In J. Cohen, M. Howard, \& M. C. Nussbaum (Eds.), Is multiculturalism bad for women? Susan Moller Okin with respondents (pp. 41-46). Princeton: Princeton University Press.

Amnesty International. (2012). Choice and prejudice: Discrimination against Muslims in Europe. London: Peter Benenson House.

Aune, K. (2011). Much less religious, a little more spiritual: The religious and spiritual views of third-wave feminists in the UK. Feminist Review, 97, 32-35. doi:10.1057/fr.2010.33

Aune, K., Sharma, S., \& Vincett, G. (2008). Women and religion in the West: Challenging secularization. Aldershot/Burlington: Ashgate.

Bracke, S., \& Fadil, N. (2009). Tussen dogma en realiteit: Secularisme, multiculturalisme en nationalisme in Vlaanderen. In K. Arnaut, S. Bracke, B. Cueuppens, S. de Mul, N. Fadil, \& M. Kanmaz (Eds.), Een leew in een kooi: De grenzen van het multiculturele Vlaanderen (pp. 93-110). Antwerpen: Meulenhoff/Manteau.

Braidotti, R. (2008). In spite of the times: The postsecular turn in feminism. Theory, Culture and Society, 25(6), 1-24. doi:10.1177/0263276408095542

Braude, A. (2004). A religious feminist - Who can find her? Historiographical challenges from the National Organization for Women. The Journal of Religion, 84, 555-572. doi:10.1086/422480

Bulbeck, C. (1998). Reorienting Western feminism: Women's diversity in a post-colonial world. Cambridge: Cambridge University Press.

Butler, J. (2008). Sexual politics, torture and secular time. The British Journal of Sociology, 59(1), 1-23. doi:10. $1111 / \mathrm{j} .1468-4446.2007 .00176 . x$

Coene, G., \& Longman, C. (2005). Eigen emancipatie eerst? Over de rechten en representatie van vrouwen in een multiculturele samenleving. Gent: Academia Press.

Coene, G., \& Longman, C. (2006). Voorbij de onzichtbaarheid of naar een verdere stigmatisering van 'dé allochtone vrouw' in een actief pluralistisch Vlaanderen? Migrantenstudies, 22, 179-198.

Coene, G., \& Longman, C. (2008). Ceci n'est pas une voile? De Belgische hijab ter discussie. Paper presented at the meeting Dag van de Sociologie, KULeuven, http://soc.kuleuven.be/ceso/dagvandesociologie/papers/ artikelhoofdoek-sociologendag-Coene-Longman.pdf

Collins, P. H. (1991). Learning from the outsider within: The sociological significance of black feminist thought. In M. Fonow \& J. Cook (Eds.), Beyond methodology: Feminist scholarship as lived research (pp. 35-59). Bloomington: Indiana University Press.

Decoene, A., \& Lambelin, J. (2009). Feminisme a-Dieu? De transformatieve kracht van feministische theologieen in België. In Sophia (Ed.), Genderstudies: Een genre apart? Een stand van zaken: Colloquium 2009 (pp. 369-392). Brussels.

Eisenstein, Z. (2004). Against empire: Feminism, racism and the West. New York: Zed Books.

Fadil, N. (2011). Not/unveiling as an ethical practice. Feminist Review, 98, 83-109. doi:10.1057/fr.2011.12

Flyvbjerg, B. (2004). Five misunderstandings about case-study research. In C. Seale, G. Gobo, I. Gubrium, \& D. Silverman (Eds.), Qualitative research practice (pp. 420-434). London: Sage.

Frankenberg, R. (1997). Displacing whiteness: Essays in social and cultural criticism. Duke University Press.

Hesse-Biber, S. N., \& Leavy, P. (2011). The practice of qualitative research. Thousand Oaks, CA: Sage.

Hewitt, L. (2011). Framing across differences, building solidarities: Lessons from women's rights activism in transnational spaces. Interface: A Journal For and About Social Movements, 3, 65-99.

Honig, B. (1999). My culture made me do it. In J. Cohen, M. Howard, \& M. C. Nussbaum (Eds.), Is multiculturalism bad for women? Susan Moller Okin with respondents (pp. 35-40). Princeton: Princeton University Press.

Hooks, B. (2000). Feminism is for everybody. New York: South End Press.

Jakobsen, J. R., \& Pellegrini, A. (2008). Secularisms. Duke University Press.

Jansz, U. (2008). De ergste vijand: levensbeschouwing en feminisme in Nederland in the tweede helft van de negentiende eeuw. Tijdschrift voor Genderstudies, 11, 19-32.

Kilic, S., Saharso, S., \& Sauer, B. (2008). Introduction: The veil: Debating citizenship, gender and religious diversity. Social Politics, 15, 397-410. doi:10.1093/sp/jxn022

Latré, B. (2011). Strijd en inkeer: De kerk-en maatschappijkritische beweging in Vlaanderen. Leuven: Leuven University Press. 
Lugones, M. C. (2006). On complex communication. Hypatia, 21, 75-85. doi:10.1111/j.1527-2001.2006. tb01114.x

Lugones, M. C. (2010). Toward a decolonial feminism. Hypathia, 25, 742-759. doi:10.1111/j.1527-2001.2010. 01137.x

Mahmood, S. (2005). Politics of piety: The Islamic revival and the feminist subject. Princeton: Princeton University Press.

McLaughlin, J. (2003). Feminist social and political theory: Contemporary debates and dialogues. London: Palgrave McMillan.

Mulder, A. C. (2002). (Over) God spreken in een multiculturele samenleving. Tijdschrift voor Genderstudies, 5, $48-55$.

Najmabadi, A. (2008). Teaching and research in unavailable intersections. In J. W. Scott (Ed.), Women's studies on the edge (pp. 69-80). Durham: Duke University Press.

Naples, N. A. (1996). A feminist revisiting of the insider/outsider debate: The 'outsider' phenomenon in rural Iowa. Qualitative Sociology, 19, 83-106. doi:10.1007/BF02393249

Nyhagen-Predelli, L., \& Halsaa, B. (2012). Majority-minority relations in contemporary women's movements: Strategic sisterhood. Basingstoke: Palgrave McMillan.

Okin, S. M. (1999). Is multiculturalism bad for women? In J. Cohen, M. Howard, \& M. C. Nussbaum (Eds.), Is multiculturalism bad for women? Susan Moller Okin with respondents (pp. 7-25). Princeton: Princeton University Press.

Parekh, B. (1999). A varied moral world. In J. Cohen, M. Howard, \& M. C. Nussbaum (Eds.), Is multiculturalism bad for women? Susan Moller Okin with respondents (pp. 69-75). Princeton: Princeton University Press.

Reilly, N. (2011). Rethinking the interplay of feminism and secularism in a neo-secular age. Feminist Review, 97 , 5-31. doi:10.1057/fr.2010.35

Scott, J. W. (2007). The politics of the veil. Princeton/Oxford: Princeton University Press.

Scott, J. W. (2009). Sexularism. In RSCAS distinguished lectures at the Robert Schumann Centre for Advanced Studies, Florence. Retrieved from http://cadmus.eui.eu/bitstream/handle/1814/11553/RSCAS_DL_2009_ 01.pdf

S'Jegers, S. (2005). Een feminisme voor alle vrouwen? De witte vrouwenbeweging in Vlaanderen in relatie tot multiculturaliteit, 'allochtone' vrouwen(organisaties) en het hoofddoekendebat (Unpublished master's thesis). VAO Vrouwenstudies, Antwerp.

Van den Brandt, N. (2012). Vrouwen in gesprek: Het kritisch oefenen en realiseren van interculturele vaardigheden in een gemengde Samenleving. In Guess who is coming for dinner: Liber Amicorum voor Rik Pinxten (pp. 77-88). Gent: Academia Press.

Weir, A. (2008). Global feminism and transformative identity politics. Hypathia, 23, 110-133. doi:10.1111/j. 1527-2001.2008.tb01436.x

Woodhead, L. (2008). Gendering secularization theory. Social Compass, 55, 187-193. doi:10.1177/ 0037768607089738

Yuval-Davis, N. (1997). Gender and nation. London: Sage.

Yuval-Davis, N. (2008). Human/women's rights and feminist transversal politics. In M. M. Ferree \& A. M. Tripp (Eds.), Global feminism: Transnational women's activism, organizing and human rights (pp. 275-295). New York: New York University Press.

Nella van den Brandt (1983) defended her dissertation entitled Religion, Secularity and Feminism in a West-European Context: A Qualitative Study of Organisations and Activism in Flanders at the 15th of December at Ghent University, Belgium. She has published in international and national academic journals such as Women's Studies International Forum, Tijdschrift voor Genderstudies, and Historica. She holds a Master degree in Comparative Women's Studies in Culture and Politics from Utrecht University, the Netherlands. She is Assistant Editor of the online journal Religion and Gender (http://www.religionandgender.org) and a Junior Member of the international research and networking project 'Interdisciplinary Innovations in the study of religion and gender: Postcolonial, Post-secular and Queer Perspectives' (http://projectreligionandgender.org/). 